沖縄島産マングースの内部寄生虫

$\square$ 公衆衛生学 $\square$ 原 著

\title{
沖縄島に生息するマングースの内部寄生虫保有調査
}

\author{
石橋 治 $^{1,2)}$, 外村浩幸 ${ }^{1)}$, 佐藤毅史 ${ }^{1)}$, 藤根誠道 ${ }^{1)}$, 川端一幸 ${ }^{1)}$, 角野敬行 ${ }^{3)}$, \\ 我如古創 ${ }^{4)}$, 浅川満彦 ${ }^{3)}$ ，小倉 剛 $^{1)}$ ，砂川勝徳 ${ }^{1)}$, 仲田 正 $^{1)}$ \\ 1）琉球大学農学部動物科学機能分野 $=903-0213$ 沖縄県西原町字千原 1 \\ 2）厚生労働省広島検疫所境出張所 干 684-0034 鳥取県境港市昭和町 9-1 \\ 3）酪農学園大学獣医学部 干 069-8501 北海道江別市文京台緑町 582 \\ 4）株式会社南西環境研究所 干 903-0105 沖縄県西原町字東崎 4-4
}

（2009 年 8 月 4 日受領，2010 年 8 月 24 日採択）

\section{Survey of Parasite Helminths in the Mongoose on Okinawajima Island}

\author{
Osamu ISHIBASHI ${ }^{1,2)}$, Hiroyuki HOKAMURA ${ }^{1)}$, Takeshi SATO ${ }^{1)}$, Masamichi FUJINE ${ }^{1)}$, \\ Kazuyuki KAWABATA ${ }^{1)}$, Takayuki SUMINO ${ }^{3)}$, Hajime GANEKO ${ }^{4)}$, Mitsuhiko ASAKAWA ${ }^{3)}$, \\ Go OGURA ${ }^{1)}$, Katsunori SUNAGAWA ${ }^{1)}$ and Tadashi NAKADA ${ }^{1)}$
}

1) Laboratory of Subtropical Zoology, Faculty of Agriculture, University of the Ryukyus, Okinawa 903-0213, Japan

2) Sakai Detached Office, Hiroshima Quarantine Station, Ministry of Health, Labour and Welfare, Tottori 684-0034, Japan

3) School of Veterinary Medicine, Rakuno Gakuen University, Ebetsu, Hokkaido 069-8501, Japan

4) Nansei Environmental Laboratory, Okinawa 903-0105, Japan

\begin{abstract}
A parasitic helminths survey was carried out on the mongoose captured on Okinawajima Island, Japan between January 2002 and September 2008. Here we report the results of several preliminary examinations conducted by various methods. Initial fecal sample survey with ether-formalin sedimentation of 186 mongooses detected the eggs of Trichuris, Hookworm, and Ascarid, as well as Coccidium oocysts in 42.5\%,22.6\%, 2.2\%, and 81.2\%, respectively, of the samples. Follow-up survey of mongooses $(n=175)$ for Angiostrongylus cantonensis infection showed that the parasite was not found in the lung and heart of any of the mongooses. Further, no Trichinella sp. larvae were obtained from the diaphragm by the compression method $(n=161)$ nor from the masseter muscle, diaphragm and the inside of hind leg by the artificial digestion method $(n=144)$ in a survey conducted 5 years later. Based on the gastrointestinal sample $(n=158)$ survey, three nematode specices (Protospirura sp. (0.6\%), Uncinaria sp. (0.6\%), Toxocara sp. (0.6\%) and one cestode species (Mesocestoides sp. (3.8\%) were detected. To examine the localization of coccidium within the alimentary tract, mongooses $(n=8)$ were kept on a controlled diet for three days, and sacrificed. Coccidia were detected in the epithelium of the duodenum and ileum from paraffin-embedded sections of 2 individuals.
\end{abstract}

Key words : helminth, Okinawajima Island, mongoose

Jpn. J.Zoo. Wildl. Med. 15(2) : 87-93, 2010

\section{序論}

沖縄島のマングース (Herpestes javanicus, 現在, 分類学的 にはH. auropunctatus とされている)（以下，マングースとす る）は, 食肉目マングース科エジプトマングース属に分類さ れる中型哺乳類である [1]。成獣の雄は, 全長 580mm で体 重 610g, 雌は 510mm で 380g である [2]。自然分布範囲は, 西はアラビア北部から東は中国南部，マレー半島，インドシナ 半島, スマトラ島, ジャワ島に分布している [1]。ハワイ諸島,
プエルトリコ, キューバ, ジャマイカ, スリナム, ドミニカ, フィ ジー諸島に導入され $[1]$, また, 沖縄島へは 1910 年に旧英 国領インドから導入された $[3,4] 。 2000$ 年に沖縄島のほぼ全 域に生息域を広げている $[5]$ 。

マングースの食性は雑食性であり, 沖縄島においては, オキ ナワキノボリトカゲ (Japalura polygonata polygonata) やアオ カナヘビ (Takydromus smaragdinus) などの爬虫類，マダラ オコオロギ (Cardiodactylus novaeguineae) などの昆虫, 節足 動物, ワタセジネズミ(Crocidura watasei)やクマネズミ(Rattus 
rattus）などの哺乳類を䬲資源として活用しており [6-8]，在 来種に対する捕食圧により島嶼固有の生物相に影響を与えてい る $[9,10]$ 。また, 沖縄島では養鵎業 $[11]$, 奄美大島におい ては農業 [12］に対する被害を与えており, マングースがヒ トの生活圈近隣にも生息していることを示している。

野生動物の生息域が人間の生活圏に近ければ, その動物とヒ トとの間にさまざまな問題が生じる。前述した産業に対する被 害に加え, ヒトや家畜に対する感染症の媒介やその野生動物に よるダニ $[13,14]$ やヒル $[15]$ などの不快昆虫等の運搬とい うヒトや家畜への危害といった問題が考えられる。これらの危 害はヒトの健康に直接関係するので, 野生動物における感染 症や寄生虫の調査は公衆衛生上の観点から重要である。沖縄島 のマングースに関する公衆衛生学的検討としては, サルモネラ $[16,17]$, レプトスピラ $[18,19], \mathrm{E}$ 型肝炎 $[20,21]$, マダ ニ［22］拈よびノミ［23］についての報告があるが, 内部寄 生虫の検討はなされていない。

わが国における野生外来動物に関する寄生虫関連の調査で は, アライグマ(Procyon lotor) からアライグマ回虫 (Bayliascaris procyonis) [24, 25]やタヌキ回虫 (Toxocara tanuki) [26], ヌー トリア (Myocastor coypus) から肝蛭（Fasciola sp.）[27] の 保有が明らかとなり, ヒトの健康および産業上の影響, さらに 野生外来動物による寄生虫相のかく乱が危惧されている [28]。 マングースについても，その内部寄生虫が他の動物に与える影 響について考慮するべきである。今般, マングースの内部寄生 虫保有調査を実施したので報告する。

\section{材料と方法}

\section{1. 材}

\section{料}

試験に供したマングースは, 2000 年 10 月以降, 沖縄県が 沖縄島において実施しているマングース駆除事業によって捕 獲した個体の一部および当研究室において捕獲した個体の計 496 頭を用いた（表 1)。捕獲したマングースを自作の保定箱
を用いてペントバルビタールナトリウム（ネンブタール ${ }^{\circledR}$ 注 射液, 大日本製薬, $35 \mathrm{mg} / \mathrm{kg}$, 腹腔内投与）により不動化し, 全採血により安楽死させた。また, 一部は捕獲後直ちに二酸化 炭素による安楽殺を行い, 個体毎にビニール袋に入れ, 剖検ま で冷凍 $\left(-20^{\circ} \mathrm{C}\right)$ 保存した。

\section{2. 方法}

1）マングースの消化管内寄生性蠕虫および原虫

検査項目とマングースの捕獲個体群の関係は表 1 のとおり である。

(1)虫卵検査

捕獲個体群 $\mathrm{A}$ のマングース (186 頭) の直腸粪を検体とした。 虫卵の分離は MGL 法 [29］にて実施した。

(2)消化管内蠕虫検索

捕獲個体群 B のマングース（138 頭）は胃噴門部から直腸 までを採取し，10％ホルマリンで固定した。固定後，消化 管内容物を取り出し，篩（100メッシュ）を用いて分類し, 70\%エタノールで洗浄した [30］。なお，剖検時に発見した虫 体については，5\%グリセリン添加 70\%エタノールにて固定 した。また, 捕獲個体群 Cのマングース（20 頭）は胃から直 腸までの消化管を固定処理せずに両鋭せん刀を用いて切開し, ラテックスグローブを装着した手指で消化管内壁を強くこす り，内容物と粘膜を採取した。採取した内容物等を篩（100 メッシュ）に移し，0.9\%生理食塩水で十分に洗浄した [31]。 得られた線虫は $5 \%$ グリセリン添加 $70 \%$ エタノールにて固定 後 [32], ラクトフェノール液で透徹し, 光学顕微鏡で形態を 観察し，検索表 [33］を用いて属を同定した。また，条虫は $10 \%$ エタノールに 5 〜 6 時間浸漬し，スライドガラスを用い て圧平して $70 \%$ エタノル中で固定した [34]。その後, HE 染色を行い, 光学顕微鏡で頭節の形状，片節の内部構造を観察 し，成書 $[34,35]$ を用いて属を同定した。

(3)原虫の検索

捕獲個体群 D のマングース（8 頭）を用いた。一般的に野生

表 1 調査に用いたマングースの個体群と検查項目

\begin{tabular}{|c|c|c|c|c|}
\hline $\begin{array}{l}\text { 捕 獲 } \\
\text { 個体群 }\end{array}$ & 捕獲年月 & 捕獲頭数 & 検査項目 & 供試頭数 \\
\hline A & $2002.1 \sim 2003.10$ & 186 & $\begin{array}{l}\text { 虫卵执よびオーシスト検索 } \\
\text { 広東住血線虫の検索 } \\
\text { 旋毛虫の検索（圧平法） }\end{array}$ & $\begin{array}{l}186 \\
175 \\
161\end{array}$ \\
\hline B & 2003. $1 \sim 2005.5$ & 138 & 消化管内蠕虫の検索 & 138 \\
\hline C & $2005.2 \sim 2005.8$ & 20 & 消化管内蠕虫の検索 & 20 \\
\hline $\mathrm{D}$ & 2006. 7 ～2006. 8 & 8 & $\begin{array}{l}\text { 原虫オーシストの㭘索 } \\
\text { 原虫の検索 }\end{array}$ & $\begin{array}{l}8 \\
3\end{array}$ \\
\hline E & $2007.10 \sim 2008.9$ & 144 & 旋毛虫の検索（消化法） & 144 \\
\hline
\end{tabular}


動物の直腸糞の中には蠕虫卵や原虫のオーシストに形態的に似 たものや餌動物由来の蠕虫卵やオーシストを検出することがあ る [36]。これらの影響を少なくするため, 捕獲したマングー スを飼育ケージ内にて魚肉ソーセージ(フィッシュソーセージ, 丸大食品製）を餌として 3 日間以上の馴化飼育をした。馴化 飼育を経過した個体は上記の 1）の手法に準じて直腸糞中の オーシストの検出をショ糖浮遊法（比重 1.203）［30］により 行った。オーシストを検出した個体について, 小腸部分（十二 指腸から回腸まで）を採取して $10 \%$ ホルマリンで固定した。 固定後, 常法に従ってパラフィン切片を作製, HE 染色を行い 鏡検（400 倍）した。

2）マングースの組織内寄生性蠕虫

(1)広東住血線虫（Angiostrongylus cantonensis）

捕獲個体群 A のマングースのうち，175 頭について心臓お よび肺臓を尖先ピンセットと解剖はさみを用いて細切し, 広東 住血線虫成虫の寄生の有無を肉眼で確認した。

(2)旋毛虫 (Trichinella spp.)

捕獲個体群 $\mathrm{A}$ のうち, 161 頭について剖検時に得られた横 隔膜（約 $1 \mathrm{~cm}^{2}$ ) をスライドガラスを用いて圧平し, 旋毛虫被 囊幼虫の有無を実体顕微鏡下で確認した。また, 捕獲個体群 $\mathrm{E}$ のマングース 144 頭では, 剖検時に得られた咬筋, 横隔膜お よび後肢上部の筋肉 $[37]$ 各およそ $0.5 \mathrm{~g}$ を人胃液消化処理し, 消化物について旋毛虫被囊幼虫の有無を実体顕微鏡下で確認し た [38]。

3）検 定 方 法

直腸粪中の蠕虫卵検出率および消化管内蠕虫の検出率の比較 にはカイ二乗検定法（有意水準 5\%）を用いた［39］。

\section{結果}

\section{1. 消化管内寄生性蠕虫および原虫}

1）直腸粪中の寄生虫卵

捕獲個体群 $\mathrm{A}$ のマングースのうち, 直腸糞から蠕虫卵若し くは原虫のオーシストを検出した個体数は 169 頭（90.9\%） であった。検出した蠕虫卵等の内訳は, 鞭虫卵 $(42.5 \%)$, 鉤 虫卵 (22.6\%), 回虫卵（2.2\%）およびオーシスト（81.2\%） であった(表2)。また,いずれの蠕虫卵等の検出率にもマングー スの性による差はなかった。

2）消化管内容物中の蠕虫

捕獲個体群 B およびCのマングースの消化管内容物から検 出された蠕虫は, 線虫類 3 種および条虫 1 種であった（表 3)。 蠕虫の寄生率は 8.2\%（13 頭）で, 線虫の寄生率は $4.4 \% （ 7$ 頭)であった。検出率にマングースの性による差はなかった(表 4)。線虫を検出したマングース 1 個体から Protospirura sp. を 3 虫体, 別の 1 個体から Toxocara sp. およびUncinaria sp. を
1 虫体ずつ検出した。残りの 5 頭から得られた線虫は生殖器の 発達が未熟であるため, 同定には至らなかった。条虫の寄生率 は 3.8\%（6 頭）であり，検出率にマングースの性による差は なかった（表 4）。小腸から検出した条虫は頭節の形状および 片節の生殖器の配列から Mesocestoides sp. と同定された。

3）原虫の検索

馴化期間を経た捕獲個体群 D のマングース（8 頭）の直腸糞 のうち，3頭（37.5\%）からオーシストを検出した。この 3 頭 のうち，1頭で十二指腸の上皮細胞内に，また，別の 1 頭では 十二指腸の上皮細胞内および回腸の上皮細胞内にコクシジウム

表 2 沖縄島産マングースにおける直腸糞中の蠕虫卵等 検出状況（2002 年 1 月～2003 年 10 月）

\begin{tabular}{cccccc}
\hline 性 & 供試頭数 & 鞭虫卵 & 銁虫卵 & 回虫卵 & オーシスト \\
\hline 雌 & 71 & 21 & 11 & 1 & 56 \\
$(\%)$ & & $(29.6)$ & $(15.5)$ & $(1.4)$ & $(78.9)$ \\
雄 & 115 & 58 & 31 & 3 & 95 \\
$(\%)$ & & $(50.4)$ & $(27.0)$ & $(2.6)$ & $(82.6)$ \\
\hline 計 & 186 & 79 & 42 & 4 & 151 \\
$(\%)$ & & $(42.5)$ & $(22.6)$ & $(2.2)$ & $(81.2)$ \\
\hline
\end{tabular}

上段は頭数，下段（）は検出率（\%) を示す。

表 3 沖縄島産マングースの消化管から検出・同定した蠕

\begin{tabular}{|c|c|c|c|c|}
\hline 分 類 & 学 名 & 寄生部位 & 寄生頭数 & 寄生数 \\
\hline \multirow[t]{3}{*}{ 線 虫 } & Protospirura sp. & 大 腸 & 1 & 3 \\
\hline & Uncinaria sp. & 小 腸 & 1 & 1 \\
\hline & Toxocara sp. & 小 腸 & 1 & 1 \\
\hline 条 虫 & Mesocestoides sp. & 小 腸 & 6 & 34 \\
\hline
\end{tabular}

表 4 沖縄島産マングースの消化管寄生性蠕虫の検出率

\begin{tabular}{|c|c|c|c|c|}
\hline \multirow{2}{*}{ 性 } & \multirow{2}{*}{ 供試頭数 } & \multirow{2}{*}{ 蠕虫寄生頭数 } & \multicolumn{2}{|c|}{ 蠕 虫 } \\
\hline & & & 線 虫 & 条虫 \\
\hline \multirow[t]{2}{*}{ 雌 } & 66 & 3 & 2 & 1 \\
\hline & & $(4.5)$ & (3.0) & (1.5) \\
\hline \multirow[t]{2}{*}{ 雄 } & 92 & 10 & 5 & 5 \\
\hline & & $(10.9)$ & $(5.4)$ & $(5.4)$ \\
\hline \multirow[t]{2}{*}{ 計 } & 158 & 13 & 7 & 6 \\
\hline & & (8.2) & $(4.4)$ & (3.8) \\
\hline
\end{tabular}

上段は頭数，下段（ ）は検出率（\%）を示す。 


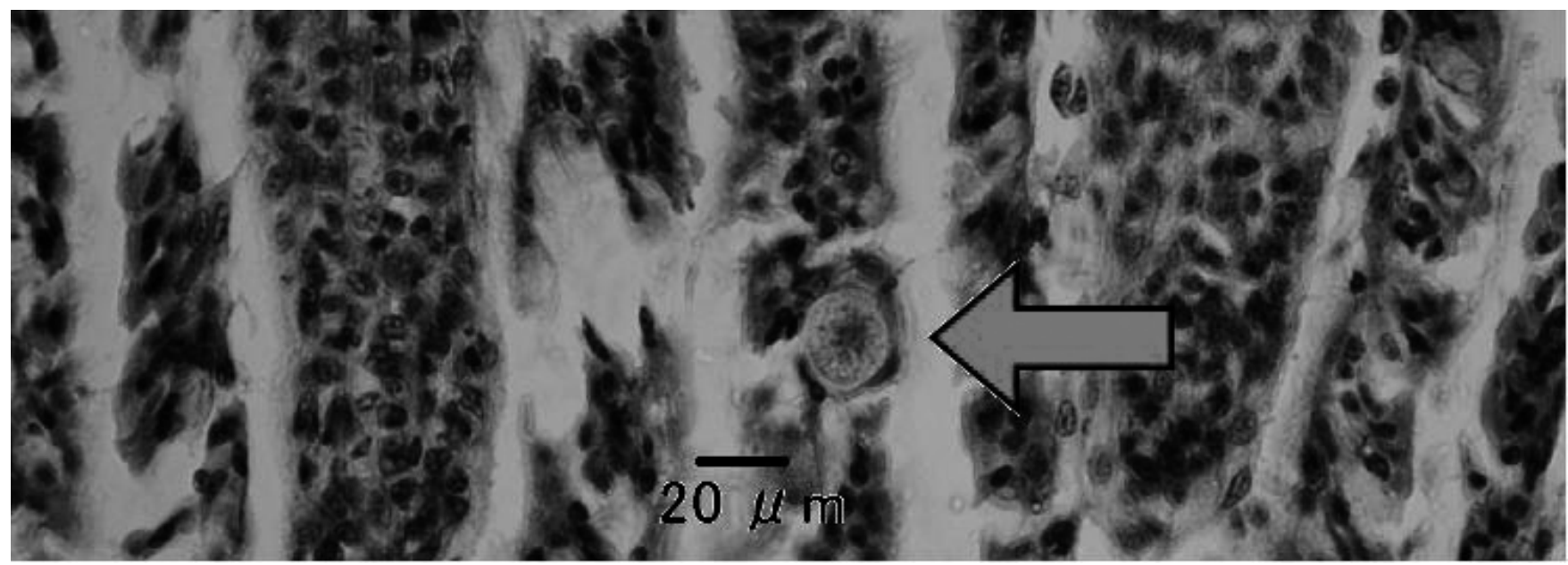

図 1 回腸上皮細胞中に認められたコクシジウム虫体

コクシジウム虫体内は細胞質がほぼ無色で，その中に赤紫色に染色された多数の核がみられる。HE 染色，Bar：20 $\mu \mathrm{m}$

の虫体が観察された（図 1)。マングースから検出されたコク シジウムは，細胞質がほぼ無色で，その中に赤紫色に染色され た多数の核が含まれているので，ミクロガーメサイトであると 判断した。

\section{2. 組織内寄生性蠕虫}

1) 広東住血線虫

捕獲個体群 Aのうち，175 頭のマングースについて心蔵お よび肺臓を精査したが, 広東住血線虫は確認されなかった。

2) 旋毛虫

捕獲個体群 Aのうち，161 頭のマングースについて横隔膜 を圧平法により精査したが, 旋毛虫被囊幼虫は確認されなかっ た。また, 捕獲個体群 Eのマングースについて咬筋, 横隔膜 および後肢内側の筋肉を人工胃液消化法により精査したが，い ずれも旋毛虫被囊幼虫は確認されなかった。

\section{考察}

マングースの直腸粪から鞭虫卵，銁虫卵，回虫卵およびコク シジウムのオーシストを確認したことから, マングースが沖縄 島において寄生虫の宿主として定着していると考えられた。し かし, 今回の直腸粪の虫卵検査ではマングースに寄生している 寄生虫由来の場合と餌動物由来の擬寄生を区別することができ ないので，検出された寄生虫卵の起原についてはさらに慎重な 検討が必要である。検出された蠕虫卵のうち, 鞭虫卵について は，形状が類似している Capillaria spp.の虫卵 [40］を見間違 えた可能性がある。海外のマングースでは Capillaria spp. の寄 生例が報告 $[41,42]$ されていることから, 沖縄島のマングー スにおける Capillaria spp. の寄生状況の調査は今後の課題とな るだろう。馴化期間を経て餌動物由来のオーシストを排除した
マングース（捕獲個体群 D）のオーシスト検出率は $37.5 \%$ で あり，捕獲後に馴化期間を設けなかった時（捕獲個体群 A）の オーシスト検出率 $(81.2 \%)$ と比べて有意に低い值 $\left(x^{2}=6.47\right.$,

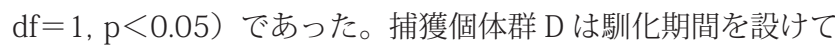
餌動物の消化管内容物由来のオーシストを検出する可能性を排 除したものなので, これが沖縄島のマングースに寄生するコク シジウムの真の寄生率と考えられた。

今回, 検出された螨虫は表 3 に示す 4 種である。このう ち, Protospirura sp. はネズミ属から報告されていること $[43$, 44], および当該線虫の寄生部位がネズミ属では胃である が, マングースでは大腸であったことから, マングースへの 寄生は餌動物であるネズミ属由来の擬寄生の可能性も考えら れた。また, Toxocara sp. はコヨーテ (Canis latrans) [45], オオカミ(Canis lupus) [45], イヌ (Canis familiaris) [31, 46], キツネ (Vulpes vulpes) [47], タヌキ (Myctereutex procyonodies) [47], ネコ (Felis catus) [48], イリオモテヤ マネコ (Mayailurus iriomotensis) [32] から, 沖縄島ではイヌ [31］から犬回虫（Toxocara canis）抢よ゙゙ネコ［48］から猫 回虫（Toxocara cati）が検出されている。Uncinaria sp. はイヌ [49]，コヨーテおよびオオカミ [45]，ツシマヤマネコ（Felis bengalensis) [50], 沖縄島では Uncinaria sp. と同科の線虫で ある Ancylostomatidae 科の犬鉤虫 (Ancylostoma caninum) を イヌ [31] から,猫鉤虫 (Ancylostoma tubaeformis) をネコ [48] から検出している。沖縄島には在来の食肉目が生息していない こと [51] およびマングースから検出された Toxocara sp. と Uncinaria sp. は, それぞれ各 1 頭のマングースから各 1 虫体 の検出であるので, 当該線虫のマングースへの寄生は伴侶動物 由来の偶発寄生の可能性が示唆された。条虫 Mesocestoides sp. 
はコヨーテ $[45,52]$, タヌキ $[47,53]$, キツネ $[54]$, テン (Martes melampus) [47], レッドウルフ (Canis rufus) [52] の食肉目から検出されている。今回, 当該条虫は全てマングー スの小腸から検出されており, 頭節を腸壁に吸着させて生存し ていたこと, 成熟片節を持っていたこと, および 6 頭のマングー スから検出されたことから，この条虫の生活環にマングースが 組み込まれていると考えられた。

マングースのコクシジウムについては, わが国のイヌやネ コに寄生するコクシジウムの大部分が Isospora 属であること [55-57] から, Isospora sp. である可能性が高いが, 今後, ス ポロシストの形成を確認することにより明らかとしたい。 今回検出した螨虫およびコクシジウムは, 沖縄島在来の寄生 虫である可能性とマングースとともに原産地より随伴侵入し た寄生虫である可能性が考えられる。沖縄島のマングースの原 産地（インド）におけるマングースの消化管内寄生性蠕虫は, Spirura ritypleurites, S. herpestis, Physaloptera sp., Trichuris sp. およびCapillaria sp. が報告されている [58]。これらは, 今回沖縄島のマングースで確認した蠕虫類と同一種ではないの で, 沖縄島のマングースの消化管内寄生性蠕虫は, 原産地から 持ち込まれたものではなく, 在来の寄生虫が寄生したものと考 えられた。

今回, 蠕虫の検出率は線虫が $4.4 \%$, 条虫が $3.8 \%$ であり, 蠕虫検出率として $8.2 \%$ であった。この検出率は沖縄島と同種

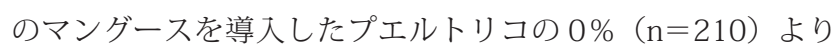
有意に高く $(p<0.05)$, グレナダの 4.9\%（ $n=1,117 ）$ と同程 度で, トリニダードの 12.5\%（n=80）[59-61］より低かった が, 有意差はなく $(p>0.05)$, マングースはそれぞれの導入 先で同様の寄生虫感染を受けていると考えられた。しかし, 沖 縄島のイヌ [31] では犬鉤虫を 53.6\%, 瓜実条虫（Dipyridium caninum）を 43.7\%，ネコ［48］では猫銁虫を 33.5\%，瓜実 条虫を $39.9 \%$ 検出しており，マングースの蠕虫寄生率より高 い状況にある。イヌやネコの行動域においては, これらの寄生 虫の感染環は既に確立されているので, これら伴侶動物の行動 域と重なる地域で生息するマングースの蠕虫寄生率は今回の調 査值より上昇すると考えられた。

マングースの心臓および肺臓から広東住血線虫は検出され なかった。この線虫は終宿主の糞中の第一期幼虫が中間宿主で あるアフリカマイマイ (Achatina fulica) やアシヒダナメクジ (Laevicalis alte) などに取り入れられ [62]，これらを終宿主 であるドブネズミ(Rattus norvegicus) やクマネズミ(Rattus rattus）が摂食することで感染環が成立する [63]。広東住血 線虫は終宿主の肺臓や心臓で成虫となり, 虫卵を体外へ排出す る [64]。ヒトにおいては, この線虫の第三期幼虫を経口摂取 することで好酸球性髄膜脳炎を起こすので，この寄生虫は公衆
衛生上重要である $[65]$ 。仮にマングースが広東住血線虫の寄 生を受けているとしても, 肺臓や心臓から虫体が発見されない ということは，成虫にならず，したがって産卵を行わないこと を示している。このことから, マングースがこの線虫の運搬者・ 増幅者として問題となる可能性は低いであろう。また, 旋毛虫 についても今回の調査では検出されなかった。わが国の旋毛虫 寄生事例は地域が極めて限定されているが [66], 家畜の移動 に伴い沖縄島に侵入することは考えられる。わが国では外来種 であるアライグマ [66] やハワイ諸島で外来種であるマングー ス [67］では旋毛虫幼虫（Trichinella sp.）の寄生事例があり， 旋毛虫の新たな宿主としてマングースが利用されることは公衆 衛生上および畜産上ともに注意が必要である。

外来動物である沖縄島のマングースが在来の寄生虫を獲得し たことはヒトや家畜への寄生虫症伝播に関する問題だけでな く, 在来動物間の寄生虫相をかく乱するという可能性がある。 マングースの寄生虫に関する定期的な調査により地域的な寄生 虫相が明らかになれば, 外来種問題を寄生虫の観点から提起す ることが可能となるだろう。

\section{謝辞}

本調査を行うに当たり，実験手技のご指導を賜りました沖縄 県衛生環境研究所安里龍二室長およびマングースの搬入に便宜 をはかってくださいました沖縄県文化環境部自然保護課に深謝 いたします。また, 調査にご協力くださいました当研究室の学 生諸氏および論文の執筆にご協力くださいました吉田裕子氏に 感謝いたします。

\section{要 約}

沖縄産マングースについて内部寄生虫の調査を行った。マン グースの直腸粪を用いて MGL 法による虫卵検査（ $\mathrm{n}=186 ） を$ 行い, 鞭虫卵 $(42.5 \%)$, 銁虫卵 $(22.6 \%)$, 回虫卵 (2.2\%) およびコクシジウムのオーシスト $(81.2 \%)$ を検出した。消 化管内容物 $(n=158)$ から, 条虫として Mesocestoides sp. （3.8\%）を，線虫として Protospirura sp. (0.6\%), Toxocara sp. (0.6\%) および Uncinaria sp. (0.6\%) を検出した。マングー ス $(\mathrm{n}=8)$ について給餌管理下で飼育し，そのうちの 2 頭の マングース小腸切片からコクシジウムの十二指腸および回腸の 上皮細胞への寄生を確認した。心臓および肺臓には広東住血線 虫 (Angiostrongylus cantonensis) の寄生はみられなかった（n $=175)$ 。また, 横隔膜の直接圧平法 $(n=161)$ および咬筋, 横隔膜および後肢内側筋肉の人工胃液消化法 $(n=144)$ では 旋毛虫（Trichinella spp.）幼虫の寄生はみられなかった。

キーワード : 内部寄生虫, 沖縄島, マングース 


\section{引用文献}

1) Nellis DW. 1989. Herpestes auropunctatus. Mamm Species $342: 1-6$.

2) Yamada F, Ogura G, Abe S. 2009. Herpestes javanicus. The wild mammals of Japan (Ohdachi S, Ishibashi Y, Iwasa M, Saitoh T eds), pp.264-266. Shoukadoh, Kyoto

3）著者不明. 1910. マングース輸入記録. 動物学杂倠誌 $22: 359$.

4）岸田久吉. 1931. 渡瀬先生とマングース輸入. 動物学杂倠誌 43: 70-78.

5）小倉 剛，川島由次，織田銑一．2003．外来動物ジャワマングースの 捕獲個体分析抢よび対策の現状と課題. 獣医畜産新報 56: 295-301.

6）川上 新. 2000. 沖縄県に扔けるマングースの移入と現状について. しまたてい 11:10-13.

7）河内紀浩, 佐々木健志. 2002. 沖縄島北部森林域に扔ける移入食肉類 （ジャワマングース・ノネコ・ノイヌ）の分布及び食性について. Biol Mag Okinawa 40: 41-50.

8）岸田久美子．2002．沖縄島北部のやんばる地域に打ける雄のジャワマ ングース Herpestes javanicus の食性. 琉球大学生産環境学科卒業論文 23pp. +9 表 +4 図.

9）阿部愼太郎. 1994. 沖縄島の移入マングースの現状. チリモス 5: 34-43.

10）小倉 剛, 佐々木健志, 当山昌直, 嵩原建二, 仲地 学, 石橋 治, 川島由次，織田銑一．2002．沖縄島北部に生息するジャワマングース （Herpestes javanicus）の食性と在来種への影響. 哺乳類科学 42: 53-62.

11）与儀元彦, 小倉 剛, 石橋 治, 川島由次, 砂川勝徳, 織田銑一. 2006. 沖縄島の養鷄業におけるマングースの被害. 沖縄畜産 41: 5-13.

12）半田ゆかり．1992．マングースによる被害一総括一．チリモス 3 28-34

13）増澤俊幸．2001。世界におけるライム病の実態と予防ワクチン。化 学療法の領域 17: 2110-2117.

14）伊東拓也, 高橋健一. 2006. エゾシカ寄生マダニ類の生態. エゾシ 力の保全と管理（梶 光一, 宮木雅美, 宇野裕之編), pp.165-181. 北 海道大学出版会, 札幌.

15）谷 重和，石川恵美子．2005．ヤマビルの生態とその防除方法. 森 林防疫 54: 87-95.

16）新田芳樹，大村修二，又吉正直，翁長友理子．2002．野生鳥獣から のサルモネラ分離と疫学的関連性, pp.33-36. 家畜保健衛生業績発表会 集録，沖縄県

17）石橋 治, 吉川貴之, 飯塚信二, 新田芳樹, 我如古創, 須藤健二, 小 倉 剛，砂川勝徳，仲田 正. 2007. 沖縄島の家畜抢よび野生動物にお けるサルモネラ調査. 琉球大学農学部学術報告 54: 47-52.

18）福村圭介. 1984. 沖縄県のレプトスピラ症の疫学的研究第 2 報 沖縄 本島におけるレプトスピラ症およびレプトスピラの血清疫学的研究. 山 口医学 33: 269-277.

19）石橋 治, 阿波根彩子, 中村正治, 盛根信也, 平良勝也, 小倉 剛, 仲地 学, 川島由次, 仲田 正. 2006. 沖緡島北部のジャワマングース (Herpestes javanicus) およびクマネズミ（Rattus rattus）におけるレプト スピラ (Leptospira spp.). 日本野生動物医学会誌 11: 35-41.

20) Li TC, Saito M, Ogura G, Ishibashi O, Miyamura T and Takeda N. 2006 Serologic evidence for hepatitis $\mathrm{E}$ virus infection in mongoose. Am. J Trop. Med. Hyg. 74: 932-936

21) Nakamura M, Takahashi K, Taira K, Taira M, Ohno A, Sakugawa H, Arai
M and Mishiro S. 2006. Hepatitis E virus infection in wild mongoose of Okinawa, Japan: Demonstration of anti-HEV antibodies and a full-genome nucleotide sequence. Hepatol Res. 34: 137-140.

22）石橋 治, 新妻 淳, 三浦彰子, 飯塚信二, 藤田博己, 小倉 剛, 坂 下光洋, 我如古創, 砂川勝徳, 仲田 正. 2009. 沖縄島のジャワマングー スに扔けるマダニ類の寄生状況. 日本野生動物医学会誌 14: 51-57

23）石橋 治, 新妻 淳, 須藤健二, 小倉 剛, 砂川勝徳, 仲田 正. 2009. 沖縄島のジャワマングース（Herpestes javanicus）におけるノミ の寄生状況.日本野生動物医学会誌 14: 67-72.

24）宮下 実. 1993. アライグマ蜔虫 Baylisascaris pyocyonis の幼虫移行 症に関する研究. 生活衛生 37: 137-151

25）佐藤 宏. 2005 . 人獣共通感染症としての回虫症ーアライグマ回虫 を中心に一。モダンメディア 51: 177-186.

26）浅川満彦，的場洋平，山田大輔，神山恒夫. 2000. 北海道野幌森林 公園を中心に生息する移入種アライグマの寄生蠕虫類を中心とした病原 生物とその伝播に関わる食性一その調査の進渉状況と今後の方向性一。 酪農学園大学紀要自然科学 25: 1-8.

27）松立大史，三好康子，田村典子，村田浩一，丸山総一，木村順平，野 上貞雄，前田喜四雄，福本幸夫，赤迫良一，浅川満彦．2003。我が国に 定着した 2 種の外来瑟歯類（タイワンリス Callosciurus erythraeus およ びヌートリア Myocaster coypus）の寄生蠕禷に関する調査. 日本野生 動物医学会誌 8: 63-67.

28）横畑泰志．2002．日本における外来哺乳類の寄生蠕禷について．日 本野生動物医学会誌 7: 91-102.

29）金子清俊, 谷口博一. 1988. 原虫・蠕虫類の検査法. 新編臨床検査 講座 医動物学 付実験用動物学, pp.77-100. 医歯薬出版, 東京.

30）今井壮一, 斉藤康秀. 1997. 原虫の形態観察. 獣医寄生虫検查マニュ アル（神谷正男，平詔 亭，茅根士郎編）, pp.12-34. 文永堂出版, 東京, 31）安里龍二, 長谷川英男, 国吉直英, 比嘉健俊. 1985. 沖縄県におけ る犬の寄生蠕虫相. 寄生虫学雑誌 34: 501-506.

32)長谷川英男. 1985. イリオモテヤマネコの寄生虫 ( I ). 沖縄島嶼研究 3 5-12.

33) Anderson R, Chabaud A and Willmott S (eds). 1974-1983. CIH keys to the nematode parasites of vertebrates. Commonwealth Agricultural Bureaux, England.

34）坂本 司. 1997. 条虫の形態観察. 獣医寄生虫検查マニュアル（今井 壮一, 神谷正男, 平 詔亨, 茅根士郎編), pp.44-55. 文永堂出版, 東京.

35）平 詔亨. 1995. 内部寄生虫 (蠕虫)。家畜臨床寄生虫アトラス (1) (平 詔亨, 藤崎幸蔵, 安藤義路編), pp.11-102. チクサン出版, 東京.

36）久米清治. 1961. 蠕虫検査法. 家畜寄生虫病診療学 (板垣四郎監修), pp.134-158. 文永堂, 東京.

37) Yimam AE, Oku Y, Nonaka N, Sakai H, Morishima Y, Matsuo K, Rosa GL, Pozio E, Yagi K and Kamiya M. 2001. First report of Trichinella nativa in red foxes (Vulpes vulpes schrencki) from Otaru city, Hokkaido, Japan. Parasitology International 50: 121-127.

38）厚生省生活衛生局．1992．食品衛生検査指針微生物編．日本食品衛 生協会, 東京. $424 \mathrm{pp}$

39）市原清志. 1990. バイオサイエンスの統計学. 南山堂, 東京. $318 \mathrm{pp}$.

40）鈴木了司. 1994. 人体寄生虫卵と原虫. 藤田企画, 弘前. $135 \mathrm{pp}$

41) Huizinga HW, Cosgrove GE, Sturrock RF. 1976. Renal capillariasis in 
the small Indian mongoose, Herpestes auropunctatus. J Wildl Dis 12: 93-96.

42) Cross JH. 1978. Kidney capillarid in the Formosan mongoose. J parasitol 64: 711 .

43）正垣幸男, 水野さほ子，伊藤秀子．1972. 名古屋市に扔いて採取し たドブネズミの線虫 Protospirura muris（Gmelin）について. 寄生虫学雑 誌 21: 28-38.

44) Hasegawa H. 1990. Protospirura okinavensis sp. n. (Nematoda:Spiruridae) from Mus caroli on Okinawa Island, Japan. J. Helminthol. soc. Wash. 57: 153-156.

45) Holmes JC and Podesta R. 1968. The helminths of wolves and coyotes from the forested regions of Alberta. Canadian Journal of Zoology 46: 1193-1204.

46) Saeki H, Masu H, Yokoi H and Yamamoto M. 1997. Long-term survey on intestinal nematode and cestode infections in stray puppies in Ibaraki prefecture. J. vet. med. sci. 59: 725-726.

47) Sato H, Ihama Y, Inaba T, Yagisawa M and Kamiya H. 1999. Helminth fauna of carnivores distributed in north-western Tohoku, Japan, with special reference to Mesocestoides paucitesticulus and Brachylaima tokudai. J. vet. med. sci. 61: 1339-1342.

48）安里龍二, 長谷川英男, 国吉直英, 比嘉健俊. 1986. 沖縄本島にお ける猫の寄生蠕虫相. 寄生虫学雑誌 35: 209-214.

49）加藤宗三郎. 1940. 朝鮮二於テ犬ヨリ得タル 1 線虫（狭頭鉤 虫) Uncinaria stenocephala railliet, 1884 二就テ. 日本獣医学雑誌 2 : 617-627.

50）安田宣紘, 丸山浩幸, 阿久沢正夫, 伊澤雅子, 三好宣彰, 清水 孜. 1992. ツシマヤマネコ（Felis bengalensis euptilura）の内部寄生虫調査. 鹿大農学術報告 42: 45-58.

51）阿部 永. 1994. 日本の哺乳類（自然環境研究センター編）。東海大 学出版会, 東京. $206 \mathrm{pp}$.

52) Custer JW and Pence DB. 1981. Ecological analyses of helminth populations of wild canids from gulf coastal prairies of Texas and Louisiana. J. parasitol. 67: 289-307.

53）久木義一. 1973. 別府市産タヌキ, Myctereutex procyonodies に寄 生していた Mesocestoides paucitesticulus について. 寄生虫学雑誌 22 300-302.
54）久木義一. 1977. ホンドキツネVulpes vulpes japonica に寄生してい た Mesocestoides paucitesticulus について. 寄生虫学雑誌 26: 25-27.

55）板垣 博, 大石 勇. 1984. 新版家畜寄生虫病学. 朝倉書店, 東京. $569 \mathrm{pp}$.

56）内田明彦, 福山正文, 平田 強, 山本静雄, 村山 洋, 荒木 潤, 橋 本 温, 三井健一. 2005. 全国の飼育犬に抢ける寄生虫感染調查とその 検査法の検討. 麻布大学杂倠誌 11/12: 227-230.

57）浅野妃美, 岩下栄一, 浅野隆司, 保刈成男, 荒島康友, 河野均也. 1994. 1979 年および 1991 年の栃木市におけるイヌの腸管内寄生虫の 分離状況. 感染症学雑誌 66: 1449-1453.

58) Chowdhury N, Aguirre AA (eds). 2001. Helminths of wildlife. Science Publishers, Enfield (NH). 514pp.

59) Espeut WB. 1882. On the acclimatization of the Indian mungoos in Jamaica. Proc zool soc London, pp.712-714.

60) Hoagland DB, Horst GR and Kilpatrick CW. 1989. Biogeography and population biology of the mongoose in the West Indies. In Biogeography of the West Indies (Woods CA ed.), pp.611-634.Sandhill Crane Press, Gainesville, Florida.

61) Hummelinck PW and Steen Van Der LJ. 1983. Parasites. Studies on the fauna of curacao and other Caribbean Islands, pp.125-131. Netherlands.

62) Asato R, Taira K, Nakamura M, Kudaka J, Itozaki K and Kawanaka M. 2004. Changing epidemiology of Angiostrongyliasis cantonensis in Okinawa prefecture, Japan. Jpn. J. infect. Dis. 57: 184-186.

63）矢部辰男. 1979. ネズミの広東住血線虫. 動物と自然 9: 7-11.

64）西村謙一.1999. 広東住血線虫症. 日本における寄生虫学の研究 7 , pp.389-408. 目黒寄生虫館, 東京.

65）井関基弘. 1987. 広東住血線虫症. 輸入感染症（竹田美文, 工藤泰雄, 倉田 毅, 高田季久編), pp.270-271. 近代出版, 東京.

66) Kobayashi T, Kanai Y, Ono Y, Matoba Y, Suzuki K, Okamoto M Taniyama H, Yagi K, Oku Y, Katakura K and Asakawa M. 2007. Epidemiology, histopathology, and muscle distribution of Trichinella T9 in feral raccoons (Procyon lotor) and wildlife of Japan. Parasitol. Res. 100: $1287-1291$.

67) Samuel WM, Pybus MJ, Kocan AA (eds). 2001. Parasitic diseases of wild mammals 2 nd ed. Iowa state university press, Ames. 559pp. 